\section{Correspondence}

http://dx.doi.org/10.11646/zootaxa.3681.1.7

http://zoobank.org/urn:1sid:zoobank.org:pub:262A4AAA-30D2-44C7-80EB-DCA59A353D46

\title{
First European records of an alien paper wasp: Polistes (Aphanilopterus) major Palisot de Beauvois, 1818 (Hymenoptera: Vespidae) in northern Spain
}

\author{
LEOPOLDO CASTRO ${ }^{1}$, ANDRÉS ARIAS ${ }^{2} \&$ ANTONIO TORRALBA-BURRIAL ${ }^{3,4}$ \\ ${ }^{1}$ Av. Sanz Gadea 9-9D, 44002 Teruel, Spain.E-mail: discoelius@discoelius.jazztel.es \\ ${ }^{2}$ Dpto. Biología de Organismos y Sistemas, Universidad de Oviedo, Oviedo 33071, Spain. E-mail: ariasandres.uo@uniovi.es \\ ${ }^{3}$ Cluster de Energía, Medioambiente y Cambio Climático, Universidad de Oviedo, Oviedo 33071, Spain. \\ E-mail: antoniotb@gmail.com \\ ${ }^{4}$ Corresponding author. E-mail: antoniotb@gmail.com
}

The frequency and speed of the transport of goods and passengers have been on the increase for decades, involving a higher rate of introductions of animals and plants to new regions that they were not able to colonise unassisted. In particular, a large number of Hymenoptera have become introduced, either deliberately (for crop pollination purposes or pest control) or unintentionally. No global data are available, but a few regional examples may outline the size of the problem: 286 hymenopteran species are known to have been introduced into Europe (Rasplus et al. 2010), 148 into New Zealand (Landcare Research 2009), 35 into the Galápagos Islands (Causton et al. 2006) and 28 into the Canary Islands (Báez \& Oromí 2010).

The introduction of vespids has become relatively common worldwide: 33 species are known as introduced, with Hawaii (15 species) and North America (8) as the main host regions (Beggs et al. 2011). Although some vespids have been translocated from certain European countries to others (Rasplus et al. 2010), only one exotic vespid, Vespa velutina Lepeletier, is known to have become established in Europe (Beggs et al. 2011).

The cosmopolitan genus Polistes Latreille is one of the most diverse among vespids (ca. 220 species: Carpenter 2008, updated). There are 10 native Polistes spp. in Europe, all in the nominotypical subgenus (Carpenter 1996a, updated), while no European records of exotic Polistinae have been published (Rasplus et al. 2010). Here we report the occurrence of a reproductively active population of the American paper wasp Polistes major major Palisot de Beauvois in northern Spain, constituting the first record of an introduced Polistes in Europe. Also, we present a diagnosis of $P$. major and discuss the potential pathways for introduction into Europe and the possible impacts that it may generate at its new location.

\section{Polistes (Aphanilopterus) major major Palisot de Beauvois, 1818}

Palisot de Beauvois 1818: 206, pl. 8 fig. 1; República Dominicana: Santo Domingo. Type depository unknown, according to Richards 1978.

Material examined. OVIEDO (Asturias, Spain): Parque del Oeste, 23.VIII.2008, photographs of $4 q$ at an immature nest with 19 cells, five of them closed and several containing one egg each (Fig. 1e), 26.V.2010, 2 \& (BOS-Hym 2 [Fig. 1a, 1b] and BOS-Hym 3); Oviedo University: Campus del Cristo, 15.II.2013, 1 §ै (BOS-Hym 1; Fig. 1c, 1d); leg. A. Arias, det. L. Castro. The collected specimens are deposited in the BOS Arthropod Collection (Departamento de Biología de Organismos y Sistemas of Oviedo University). The sites are at $43^{\circ} 21^{\prime} \mathrm{N}, 5^{\circ} 52^{\prime} \mathrm{W}$, at an altitude of $200-300 \mathrm{~m}$ and rather less than $1 \mathrm{~km}$ from each other; they are both parks or green spaces in an urban matrix.

Diagnosis. The genus Polistes is defined by the combination of the following character states: metasomal segment 1 subsessile, subconical in dorsal view; propodeal foramen very long and dorsally rather narrow; pronotum posterior angles with a pretegular carina; metasomal tergum 2 not fused with sternum 2; dorsal carina of pronotum complete, almost reaching ventral angle of propleura (Richards 1978; Carpenter 2004). The genus consists mainly of primitively eusocial species, with some members living as social parasites of congeneric species (Hunt 2007). Nests are built with paper made by chewing wood, and have just one comb (which typically hangs from a single pedicel) and no envelope. 

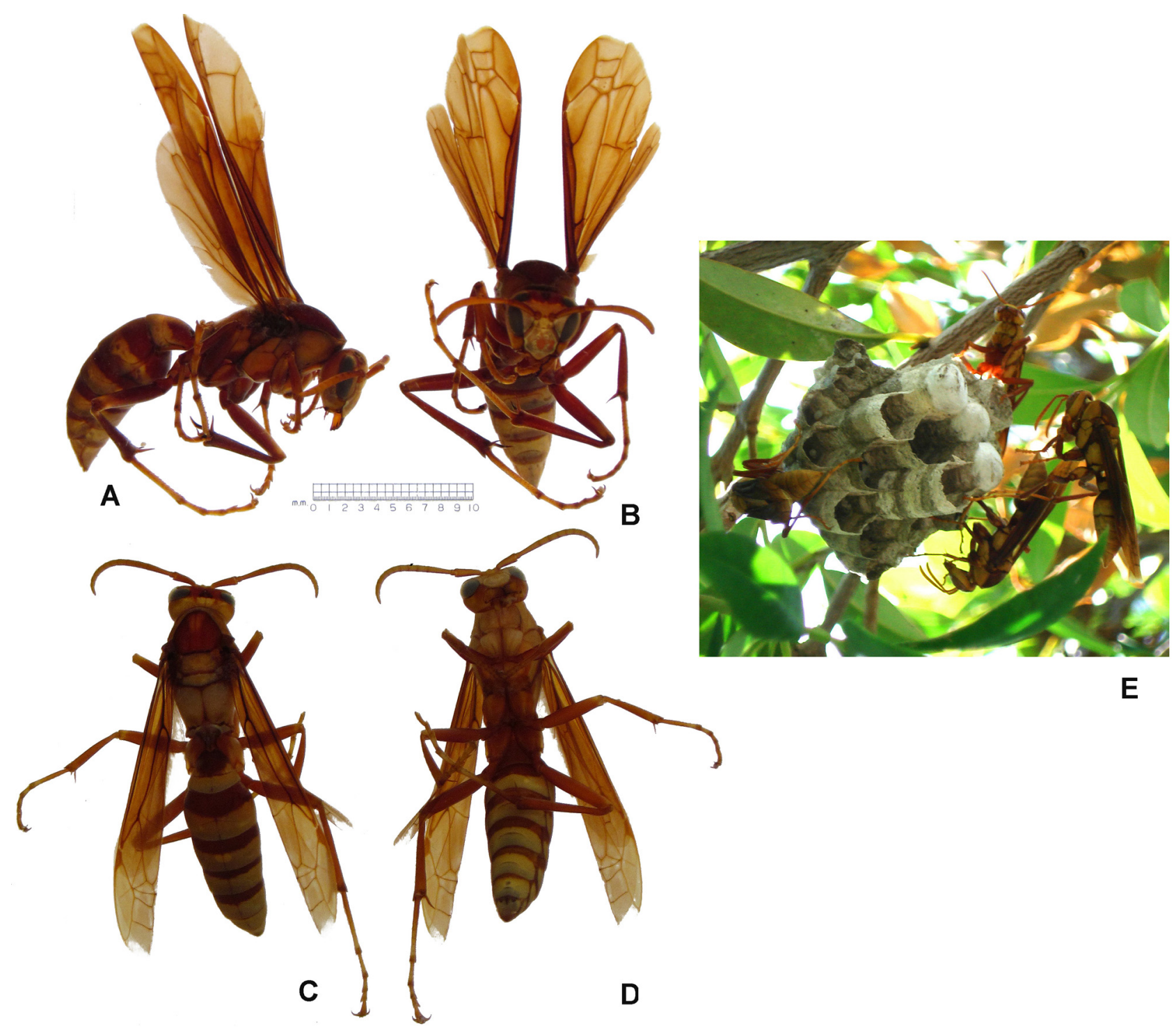

E

FIGURE 1. Polistes major from northern Spain. A. Lateral view; B. Frontal view; C. Dorsal view; D. Ventral view; E. Nest photographed in 2008, showing several females and eggs. A \& B female BOS-Hym 2; C \& D male BOS-Hym 1.

All the native American species belong to subgenus Aphanilopterus Meunier, characterised by lateral pronotal foveae usually present; clypeus not produced posteriorly beyond the anterior tentorial pits; dorsal pronotal carina usually blunt (not lamellate) above the foveae; parastigma generally much shorter than pterostigma and apically straight; mesepisternal punctation sparse; male antennae without apical hook (Carpenter 1996b).

The general morphology of $P$. major is similar to that of European Polistes spp., but its size and colour pattern readily differentiate it (Fig. 1). This American wasp is distinctly larger than European polistines: body length = 17-22 mm, wingspan ca. $45 \mathrm{~mm}$; European Polistes: body length = 11-18 mm, maximum wingspan $30 \mathrm{~mm}$ (Richards 1978; LC, unpublished). Furthermore, P. major major is largely yellow with some brown areas (Fig. 1), whereas European Polistes have a black and yellow pattern. Other differences involve the mesopleuron (without striae in $P$. major, with dense irregular microstriae in the European spp.), the propodeum (ridges disappearing laterally before reaching metapleuron in P. major, strong and always reaching metapleuron in European spp.) and the male antennae, without apical hooks in $P$. major (Carpenter 1996b).

The specimens belong to subspecies $P$. major major. Small yellowish patches at the sides of the metasomal scutum and a very wide yellow apical band on metasomal tergum 1 seem to suggest some connection to ssp. colombianus Bequaert, with an almost entirely yellow body. Nevertheless, many Polistes spp. show wide variation in individual coloration without geographic patterns associated. 
Biology. Information about the biology of Polistes major is scarce. The nests, with a central pedicel and a maximum diameter of nearly $19 \mathrm{~cm}$, are typically under eaves, bridges or culverts or hanging from branches or metal beams (Richards 1978). It preys mainly on caterpillars (Cameron 1986) and membracid nymphs (Dowell \& Johnson 1986; Cocroft 2002). Cameron (1986) and Wenzel (1987) comment on several aspects of male reproduction behaviour and brood care.

Distribution. Its native range extends, in several subspecies, from the south of the United States to Peru and southern Brazil, including the Caribbean islands (Carpenter 1996a). In California and Baja California it is replaced by a close relative, Polistes palmarum Bequaert, and to the south of its range by another similar species, Polistes paraguayensis Bertoni, which occurs in southern Brazil, Paraguay, Bolivia and north-eastern Argentina (Carpenter 1996a).

Polistes major has been found in Oviedo repeatedly between 2008 and 2013, suggesting its establishment in this area, but several introduction events cannot be excluded. The fact that it has nested in the area suggests that the local conditions are compatible with the wasp's bioclimatic profile and that this alien species might spread to other parts of the Cantabrian area with similar environmental characteristics.

The introduction pathway of this species into Europe is so far unknown, but some previous accidental vespid introductions have been linked to imported goods (Beggs et al. 2011). In the case of P. major major in northern Spain, shipping would be one of the most plausible ways of introduction, since the collecting sites are a relatively short distance (some $25 \mathrm{~km}$ ) from a port area where wood and fruit arrive on a regular basis, in merchant vessels, from North and Central America.

Invasive potential and possible impacts. Some naturalised vespids have become invasive species with negative effects in their new habitats. Impacts are mostly ecological (competition for food with, or predation on, the native fauna) and economic (damage to fruit or derived products), but there are also health risks involved. Beggs et al. (2011) consider seven vespids as invasive species: of these, the only one relevant in the European context is Vespa velutina, an Asian vespine that has invaded about two thirds of the French territory (Rome et al. 2011) and is currently advancing in northern Spain and Portugal (Castro \& Pagola-Carte 2010; Grosso-Silva \& Maia 2012). This hornet is an active hunter of honey bees and has been inflicting serious economic damage on beekeeping since its arrival in Europe (Rome et al. 2011).

The invasive potential of alien Polistes species, like Polistes dominula (Christ) in North America, Polistes chinensis (Fabricius) in New Zealand and Polistes versicolor (Olivier) in the Galápagos Islands, has been assessed and confirmed (Beggs et al. 2011). Impacts on insect communities, mainly on Lepidoptera (Polistes commonly preys on lepidopteran larvae), have been observed where invasive Polistes species reach high population densities (Clapperton 1999; Causton et al. 2006), but quantification of these impacts remains unclear (Beggs et al. 2011). In North America, field studies on competitive interactions between the alien $P$. dominula and the native American paper wasps have evidenced advantages for $P$. dominula, which can displace the indigenous species (Liebert et al. 2006). In Europe the native $P$. dominula is very abundant, and could reduce the expansion possibilities of the exotic P. major. Finally, introduced species can also act as vectors of foreign pathogens and other associated non-native organisms which could affect native paper wasps.

The abundance of P. major in northern Spain has not been investigated, but presumably it is not high, given the low number of detections since 2008, and consequently effects on local insect biodiversity do not seem likely at the moment. However, both the evolution of this population and its eventual spread in northern Spain should be monitored: learning about its biology in Europe could be useful to control the wasp in the future if $P$. major became invasive.

Finally, another important concern is this alien species' potential as a health hazard for humans. Polistes species can sting people, in particular when wasps' nests are disturbed or at swimming pools, although their venom is dangerous only to allergic or hypersensitive people. A relatively big wasp like $P$. major may inoculate a larger dose of venom than the native species, and medical treatments available in Spain may or may not be effective, since Polistes venom is speciesspecific and substantial differences may exist between the composition of American wasps' venom and that of the European species (Turillazzi 2006).

\section{Acknowledgments}

AA is supported by a Severo Ochoa FICYT grant; ATB by a PTA cofinanced contract of the R+D+I National Plan and PCTI Asturias. We thankfully acknowledge the positive suggestions of anonymous reviewers. 


\section{References}

Báez, M. \& Oromí, P. (2010) Hymenoptera. In: Arechavaleta, M.S., Rodríguez, Z., Zurita, N. \& García, A. (coord.), Lista de especies silvestres de Canarias. Hongos, plantas y animales terrestres. 2009. Gobierno de Canarias, pp. 343-366.

Beggs, J.R., Brockerhoff, E.G., Corley J.C., Kenis, M., Masciocchi, M., Muller, F., Rome, Q. \& Villemant, C. (2011) Ecological effects and management of invasive alien Vespidae. Biocontrol, 56, 505-526. http://dx.doi.org/10.1007/s10526-011-9389-z

Cameron, S.A. (1986) Brood care by males of Polistes major (Hymenoptera: Vespidae). Journal of the Kansas Entomological Society, 59, 183-185.

Carpenter, J.M. (1996a) Distributional checklist of species of the genus Polistes (Hymenoptera: Vespidae; Polistinae, Polistini). American Museum Novitates, 3188, 1-39.

Carpenter, J.M. (1996b) Phylogeny and biogeography of Polistes. In: Turillazzi, S. \& West-Eberhard, M.J. (Eds.), Natural History and Evolution of Paper-Wasps. Oxford University Press, Oxford, pp. 18-57.

Carpenter, J.M. (2004) Synonymy of the genus Marimbonda with Leipomeles (Hymenoptera: Vespidae; Polistinae), and a new key to the genera of paper wasps of the New World. American Museum Novitates, 3465, 1-16. http://dx.doi.org/10.1206/0003-0082(2004)465\%3C0001:sotgmr\%3E2.0.co;2

Carpenter, J.M. (2008) Review of Hawaiian Vespidae (Hymenoptera). Bishop Museum Occasional Papers, 99, 1-18.

Castro, L. \& Pagola-Carte, S. (2010) Vespula velutina (Hymenoptera: Vespidae), recolectada en la Península Ibérica. Heteropterus Revista de Entomología, 10, 193-196.

Causton, C.E., Peck, S.B., Sinclair, B.J., Roque-Albelo, L., Hodgson, C.J. \& Landry, B. (2006) Alien insects: threats and implications for conservation of Galápagos Islands. Annals of the Entomological Society of America, 99, $121-143$. http://dx.doi.org/10.1603/0013-8746(2006)099[0121:aitaif]2.0.co;2

Clapperton, B.K. (1999) Abundance of wasps and prey consumption of paper wasps (Hymenoptera, Vespidae: Polistinae) in Northland, New Zealand. New Zealand Journal of Ecology, 23, 11-19.

Cocroft, R.B. (2002) Antipredator defense as a limited resource: unequal predation risk in broods of an insect with maternal care. Behavioral ecology, 13, 125-133. http://dx.doi.org/10.1093/beheco/13.1.125

Dowell, R.V. \& Johnson, M. (1986) Polistes major (Hymenoptera, Vespidae) predation of the treehopper, Umbonia crassicornis (Homoptera, Membracidae). The Pan-Pacific entomologist, 62, 150-152.

Grosso-Silva, J.M. \& Maia, M. (2012) Vespa velutina (Hymenoptera, Vespidae), new species for Portugal. Arquivos Entomolóxicos, 6, 53-54.

Hunt, J.H. (2007) The evolution of social wasps. Oxford University Press, New York, xxii + 260 pp.

Landcare Research (2009) Checklist of New Zealand Hymenoptera v7.0. Available from: http://www.landcareresearch.co.nz/ resources/collections/nzac/holdings/primary-type-specimens-hymenoptera/checklist-hymenoptera (Accessed 18 Mar. 2013)

Liebert, A.E., Gamboa, G.J., Stamp, N.E., Curtis, T.R., Monnet, K.M., Turillazzi, S. \& Starks, P.T. (2006) Genetics, behavior and ecology of a paper wasp invasion: Polistes dominulus in North America. Annales Zoologici Fennici, $43,595-624$.

Palisot de Beauvois, A.M.F.J. (1805-1821) Insectes recueillis en Afrique et en Amérique, dans les royaumes d'Oware et de Benin, à Saint-Domingue et dans les États-Unis, pendant les années 1786-1797. Imprimerie de Fain et Compagnie, Paris, XVI + 276 pp., 90 pls. [Published in 15 livraisons, each with 6 plates and text; the index to species is in livraison 15, pp. 269-276][ (1805) I-XVI, 1-40; (1806) 41-56; (1807) 57-88; (1809) 89-100; (1811) 101-136; (1817) 137-172; (1818) 173-208; (1819) 209-224; (1820) 225-240; (1821) 241-246 (Dating from Evenhuis 1997)]

Rasplus, J.-Y., Villemant, C., Paiva, M.R., Delvare, G. \& Roques, A. (2010) Hymenoptera. Chapter 12. Alien terrestrial arthropods of Europe. BioRisk, 4, 669-776. http://dx.doi.org/10.3897/biorisk.4.55

Richards, O.W. (1978) The social wasps of the Americas excluding the Vespinae. British Museum (Natural History), London, viii + 580 pp., 4 pl.

Rome, Q., Perrard, A., Muller, F. \& Villemant, C. (2011) Monitoring and control modalities of a honeybee predator, the yellow-legged hornet Vespa velutina nigrithorax (Hymenoptera: Vespidae). Aliens: The Invasive Species Bulletin, 31, 7-15.

Turillazzi, S. (2006) Polistes venom: a multifunctional secretion. Annales Zoologici Fennici, 43, 488-499.

Wenzel, J.W. (1987) Male reproductive behavior and mandibular glands in Polistes major (Hymenoptera: Vespidae). Insectes sociaux, 34, 44-57. http://dx.doi.org/10.1007/bf02224206 